Int. J. Dev. Biol. 49: 335-347 (2005)

doi: $10.1387 / \mathrm{ijdb} .041946 \mathrm{ag}$

\title{
Antero-posterior patterning of the vertebrate digestive tract: 40 years after Nicole Le Douarin's PhD thesis
}

\author{
ANNE GRAPIN-BOTTON* \\ Swiss Institute for Experimental Cancer Research (ISREC), Epalinges, Lausanne, Switzerland
}

\begin{abstract}
This review is dedicated to the work on chick digestive tract organogenesis that Nicole Le Douarin performed as a PhD student under the direction of Etienne Wolf. I discuss how she laid the grounds for future work by establishing fate maps at somitic stages, by describing morphogenetic movements between germ layers and by pointing to signaling events between endoderm and mesoderm. Her inspiring work was extended by others, in particular at the molecular level, leading to a better understanding of antero-posterior patterning in the digestive tract. Antero-posterior patterning of endoderm is initiated at gastrulation when future anterior and posterior endoderm ingress at different times and accordingly express different genes. Plasticity is however maintained at somite stages and even later, when organ primordia can be delineated. There is a cross-talk between endoderm and mesoderm and the two layers exchange instructive signals that induce specific antero-posterior identities as well as permissive signals required for organogenesis from previously patterned fields. Recent experiments suggest that several signaling molecules involved in neural tube antero-posterior patterning are also instrumental in the digestive tract including retinoic acid and FGF4.
\end{abstract}

KEY WORDS: endoderm, gut, axis, signaling, chick

\section{Introduction}

Nicole Le Douarin's name is often associated with quail-chick chimeras and the fantastic jump triggered by the use of this technique to study neural crest cell derivatives. Less is known about her early work on digestive tract organogenesis, which started when she was a PhD student under the direction of Etienne Wolf in Nogent. The fact that this work was mainly published in French makes it less accessible but nevertheless very insightful. The purpose of this review is to draw attention to her early work and show how it inspired developmental biologists since then. The first of her main achievements was the establishment of a fate map of the 10-25-somite-stage chick endodermal and mesodermal territories that give rise to different organs of the digestive tract and the observation of interesting sliding movements between these two layers. The second contribution concerns the requirement for interactions between endoderm and mesoderm during the specification of domains in the digestive tract. This work was pursued in many labs including those of Michèle Kedinger, Kathy Haffen, Sadao Yasugi and more recently ours. In particular, N. Le Douarin demonstrated the requirements for cardiac mesoderm and later septum transversum in liver induction and organogenesis. These findings were recently extended to the mouse and studied at the molecular level by Ken Zaret and coworkers. Forty years later, our overall comprehension of how organs are laid out along the antero-posterior $(A-P)$ axis is less extensive in the digestive tract than in the neural tube with which parallels in the mechanism and molecules involved can nevertheless already be drawn.

\section{A crude and unstable A-P asymmetry in endoderm after gastrulation}

How organ formation correlates with specific regions of the flat endodermal sheet has been a recurrent question, asked as early as 1874 when His published a map of the presumptive digestive and respiratory organs of the chick blastoderm (His, 1874). Fatemapping experiments have traced the fate of cells in the definitive digestive organs prior to or just after gastrulation in many species.

\footnotetext{
Abbreviations used in this paper: AIP, anterior intestinal portal; AP, anteroposterior; CIP, caudal intestinal portal; IFABP, intestinal fatty acid binding protein; LPM, lateral plate mesoderm.
} 

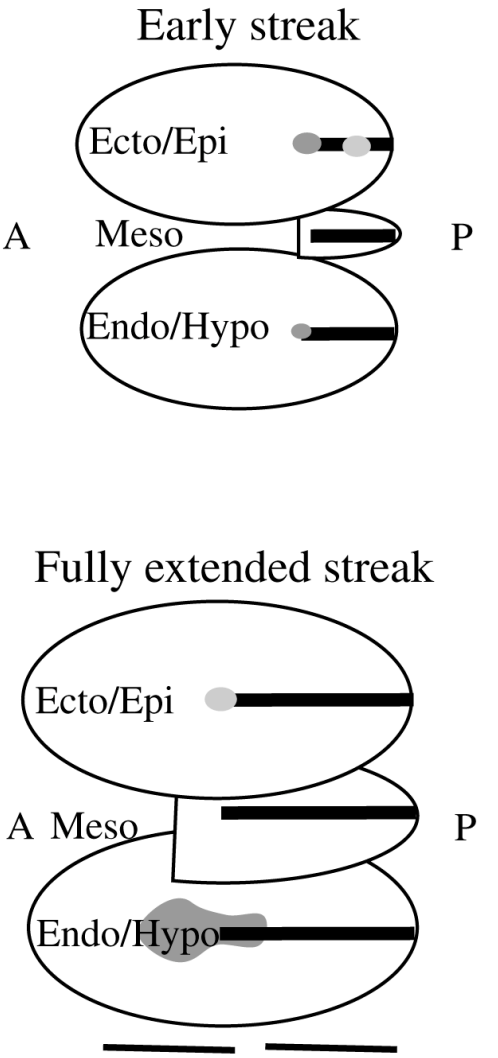

Lim1, Foxa2, Otx2, Gsc, Fgf8, Bmp2,4,7, Hex, Cres, Dkk1, Cer Cdxs

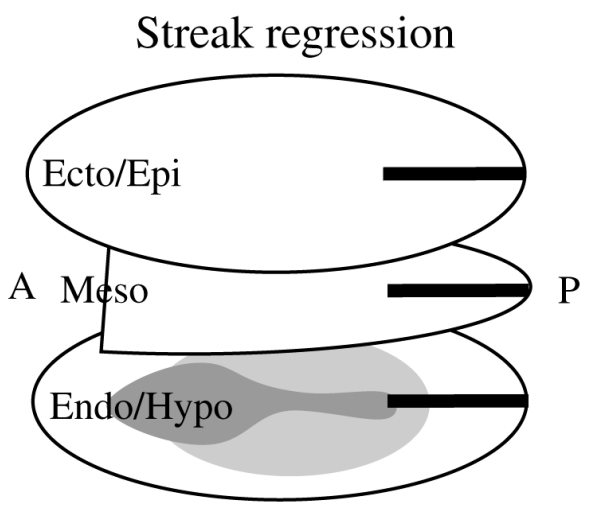

Lim1, Foxa2, Otx2, Gsc, IFABP Hex, Cres, Dkk1, Cer

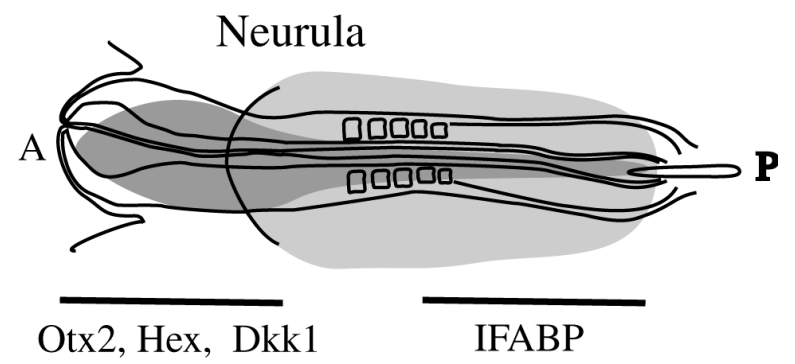

As early as the 32-blastomere stage in Xenopus it was shown that ventral vegetal blastomeres tend to give progeny in more posterior endoderm areas than dorsal blastomeres (Dale and Slack, 1987; Moody, 1987) In zebrafish, labeling of single cells located in the margin of the 1000/3000-cell gastrula reveals that different regions give rise to a specific subset of organs but single cells contribute to several organs (Warga and Nusslein-Volhard, 1999). In chick, fate-mapping of endoderm precursors in epiblast and primitive streak have shown that at early streak stage endoderm precursors are found throughout the streak and become restricted to the tip of the streak by late streak stage (Hatada and Stern, 1994, Psychoyos and Stern, 1996)(and abundant former literature herein)(Lawson and Schoenwolf, 2003; Kirby et al., 2003). The most posterior streak endoderm precursors give rise to more posterior and lateral endoderm (Lawson and Schoenwolf, 2003, Rosenquist, 1972). These results are compiled in figure 1 . In the mouse, Lawson and co-workers traced the derivatives of the epiblast (Lawson et al., 1986, Lawson et al., 1991) and outer layer (Lawson and Pedersen, 1987) in prestreak and early streak stage embryos using horseradish peroxydase injections (6.7 and 7.5 days post-coitum, dpc). As in chick, definitive endoderm cells derive from the distal PS and gradually replace the primitive endoderm, starting with the most anterior cells (Kinder et al., 2001). Fate mapping and gene expression analysis also indicate that different endoderm populations exit the streak in a defined order, starting with Hex (Hematopoietically expressed homeobox) -positive cells which colonize mainly the ventral foregut (Thomas et al., 1998) and followed by cells expressing the forkhead transcription factor FoxA2, forming dorsal foregut, midgut and eventually the hindgut (Ang and Rossant, 1994, Dufort et al., 1998, Lawson et al., 1986).

Many other markers are asymetrically expressed after gastrulation as shown in Fig. 1. As groups of mesodermal and endodermal cells remain associated during and after gastrulation, gene expression is often reported in mesendoderm rather than endoderm (Parameswaran and Tam, 1995) (Kinder et al., 1999, Tam et al., 1997). Functionally, A-P asymmetry is demonstrated

Fig. 1. Spatial organization of endoderm at gastrulation and headfold stage in the chick. The three layers are schematically dissociated, epiblast/ectoderm on top, mesoderm in the middle, hypoblast/endoderm at the bottom. Anterior/midline endoderm is in dark grey and posterior/ lateral endoderm is in pale grey. The presence of endodermal cells in transit in the middle layer has not been assessed. The dark line is the primitive streak. A refers to anterior and $P$ to posterior. Anterior markers are the transcripts for the secreted proteins Cerberus 1 (Cer) (Belo et al., 1997; Biben et al., 1998; Chapman et al., 2002), Dickkopf1 (Foley et al., 1997; Glinka et al., 1998; Pearce et al., 1999), Crescent (Pfeffer et al., 1997) and the homeobox transcription factors Orthodenticle homeobox (Otx) 2 (Ang et al., 1994; Bally-Cuif et al., 1995), Goosecoid (IzpisuaBelmonte et al., 1993; Blum et al., 1992), Hex (Thomas et al., 1998; Yatskievych et al., 1999) and Lim Homeobox 1 (Lim1) (Chapman et al., 2002; Shawlot and Behringer, 1995) as well as FoxA2 (Alexander and Stainier, 1999; Ang et al., 1993; Ruiz i Altaba et al., 1995), Her5 (Bally-Cuif et al., 2000). Many of these genes are also expressed in the primitive endoderm in the AVE in addition to definitive endoderm (Rodriguez et al., 2001). Posterior markers of endoderm are more scarce but one of them is Intestinal fatty acid binding protein transcript (IFABP) (Wells and Melton, 2000). Many posterior markers like Fgf8, Bmp 2,4,7, Cdxs (Chapman et al., 2002; Marom et al., 1997) are expressed in the posterior streak where layers can not be distinguished. 
Endoderm Gut tube Mesoderm

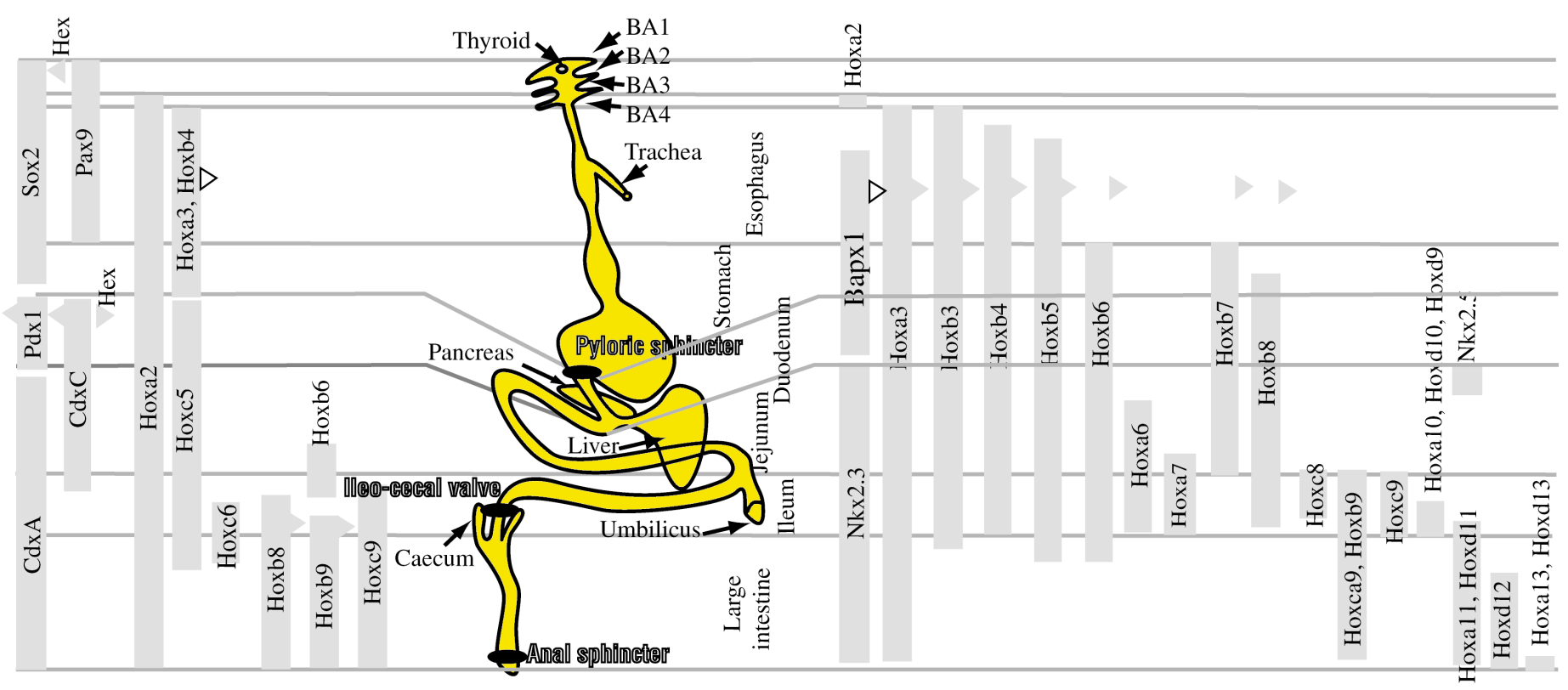

Fig. 2. Regionalization of endoderm from somitogenesis to organogenesis. Many transcription factors are expressed in restricted domains of endoderm and mesoderm. This pattern progressively arises as somitogenesis begins. The gene expression boundaries are based on in situ hybridization on sections performed by the author and published data, all at embryonic day 4 (E4) in the chick (Grapin-Botton and Melton, 2000, Sakiyama et al., 2000, Sakiyama et al., 2001, Yokouchi et al., 1995). There are some discrepancies with other sources using PCR for detection, different stages and species (Beck et al., 2000). The triangles represent the thyroid (left), trachea and lungs (right), liver (right), pancreas (left) and caeca from up to down.

by the specific ability of the anterior endoderm to induce heart differentiation in the mesoderm at the same stages (Marvin et al., 2001, Narita et al., 1997, Schultheiss et al., 1995). The initial formation of the rostral and caudal endoderm is affected by different genes. When the forkhead transcription factor Sox17 or the BMP signaling pathway genes FoxH1 or smad2 are inactivated, only the posterior gut, ingressing later, is affected (Hoodless et al., 2001, Kanai-Azuma etal., 2002, Tremblay etal., 2000, Yamamoto et al., 2001). On the contrary, FoxA2-knockout cells can form hindgut but not fore- and midgut (Dufort et al., 1998).

The segregation between anterior and posterior precursors also takes place very early in several invertebrates. In sea urchin, two types of endoderm precursors are segregated prior to gastrulation, veg1 and veg2 cells that contribute respectively to the archenteron base and tip (Logan and McClay, 1997) and accordingly gastrulate at different times. In $C$. elegans, the endodermal precursor, the E cell divides along the antero-posterior axis to give rise to Ea and Ep prior to gastrulation. Ea eventually gives rise to anterior gut derivatives and $\mathrm{Ep}$ to the posterior gut. This pattern is intrinsic to the cells since ablation of Ea or Ep ablates anterior or posterior gut respectively (Schroeder and McGhee, 1998). Anterior and posterior endoderm anlage are also segregated early in Drosophila (Reuter et al., 1993).

In spite of the regional expression of genes, their expression is still plastic.Wells and Melton (2000) showed that at 7.5dpc anterior endoderm associated with posterior mesendoderm turns on several posterior markers and off some anterior ones (Wells and Melton, 2000). The converse is also true. Posterior specification might be mediated in part by fibroblast growth factor (FGF) 4, a secreted protein expressed in the posterior half of the embryo at this time (Niswander and Martin, 1992, Wells and Melton, 2000). Fgf4 inactivation is deleterious shortly after implantation, so far precluding a validation for its requirement in A-P patterning in vivo (Feldman et al., 1995).

\section{As somites form, a complex gene expression map prefigures organogenesis in endoderm and mesoderm}

Some of the early anterior endoderm markers are lost between gastrulation and neurulation as it is the case for GsC, Lim1 and Crescent, Others like Hex are maintained. A last category is turned on as somitogenesis begins, like $P d \times 1, C d \times 2 / A$, Sox2 and 3, Nkx2.1 and Hox genes. According to fate mapping experiments in the chick and to their maintenance during organogenesis, it can be inferred that they are restricted to the precursor fields of specific organs. In the 15-somite-stage chick, domains that contribute to various digestive organs do overlap although regions of different fates can be distinguished (Le Douarin, 1964b, Matsushita, 1996, Matsushita, 1999). There is only one fate mapping study at this stage in the mouse and it largely corroborates the chick data (Tremblay and Zaret, 2005).

Accordingly there are at least 6 domains with different gene expression profiles at this stage and they are maintained after organogenesis (Fig. 3) (Grapin-Botton and Melton, 2000).

As Hox genes play a major role in A-P patterning in other germ layers, a particular attention should be given to these genes. Most of the Vertebrate Hox genes are expressed in splanchnic mesoderm but only a subset is expressed in the endoderm at 
levels detectable by in situ hybridization (Fig. 2). Similarly, in Drosophila, labia/ is the only Hox gene expressed in the endoderm whereas more Hox genes are expressed in mesoderm. The anterior expression limits of Hox genes in the endoderm do not always correlate with boundaries between organs but there are hotspots of Hox boundaries at the levels of sphincters (pyloric, ileocaecal, anal) (Roberts, 2000). Hox gene inactivation may lead to digestive tract malformations as reported for Hoxa3 (Manley and Capecchi, 1995, Manley and Capecchi, 1998), Hoxa5 (Aubin etal., 1999, Aubin et al., 2002, Aubin et al., 1997), Hoxc4 (Boulet and Capecchi, 1996), Hoxa13 and Hoxd13 (Warot et al., 1997) and Hoxa4 (Tennyson et al., 1993, Tennyson et al., 1998). Their inactivation does generally not result in homeotic transformations, possibly due to redundancy although redundancy does not preclude from observing homeotic transformations of vertebrae in the mesoderm. Among experimental anterior expansions of Hox gene expression, only that of Hoxa13 in the mesenchyme leads to induction of hingut fate in the midgut (Roberts et al., 1998). Others induce malformations rather than posterior transformations (Pollock et al., 1992, Tennyson et al., 1993, Tennyson et al., 1998). There is only one example of Hox gene playing a direct role in endoderm which concerns Hoxa13 in the hindgut (de Santa Barbara and Roberts, 2002).

Another homeobox gene complex, the so-called ParaHox cluster, shown in Amphioxus to contain homologues for the genomic screened homeobox (Gsh1) gene, pancreatic-duodenumhomeobox $1(P d \times 1)$ and Caudal homologue $C d \times 2$, might play a role in A-P patterning (Brooke et al., 1998). This cluster although not strictly endoderm-specific seems to be mostly implicated in endoderm development. Although Gsh1 is not expressed in endoderm is Vertebrates, it is expressed in endoderm in other groups, including Cnidarians (Yanze et al., 2001). The genes are expressed orderly along the A-P axis, Gsh being the most anterior and $C d \times 2$ the most posterior. Gain-and loss-of-function experiments demonstrated that in other germ layers than endoderm, $C d x 1 /$ $X \mathrm{cad} 3$ directly activates Hox genes and it may have the same properties in endoderm (Bel-Vialar etal., 2002, Charite etal., 1998, Epstein et al., 1997, Isaacs et al., 1998, Pownall et al., 1996, van den Akker et al., 2002). It may as well be a repressor of some Hox genes since the posterior expression boundaries of Hoxa3 and Hoxb4 correspond to the anterior limits of $P d \times 1$ and $C d \times C / C d \times 2$ expression (Fig. 2). Gene inactivation of $C d x 2$ clearly results in homeotic transformations. $C d \times 2$ heterozygotes exhibit induction of stomach tissue in the mid- and hindgut (Beck et al., 1999). Stomach is the identity of the digestive tract immediately anterior to $C d x 2$ expression domain. $P d x 1$ inactivation results in pancreas atrophy and defects in the most anterior duodenum but it is not an anterior transformation (Offield et al., 1996). Whether their effect is strictly relayed by $H o x$ genes is unlikely since $P d x 1$ and $C d x 2$ directly activate genes playing a role in adult organ function (insulin (Ohneda et al., 2000), lactase-phlorizin (Troelsen et al., 1997), sucrase isomaltase (Suh et al., 1994).

\section{Morphogenetic events and their relation to A-P patterning}

The gene expression patterns described above are established as complex morphogenetic movements shape the gut tube from a flat (as in chick or human) or cup-shaped (as in rodents) layer of cells. The mouse and chick gut tubes form from a crescent-shaped fold, the so-called anterior intestinal portal (AIP), which appears in the endoderm at the anterior tip of the embryo when somitogenesis begins (Fig. 3)(Bellairs, 1953, His, 1874). This fold progresses posteriorly. A similar fold, called the caudal intestinal portal (CIP), arises later at the posterior end of the embryo and moves anteriorly (Fig. 3)(Gaertner, 1949, Gasser, 1880). The two folds meet at the yolk stalk. N. Le Douarin used carbon particles to mark the AIP between 8 and 12 somite-stage and observed that a streak of particles was deposited in the ventral midline from esophagus to preumbilical small intestine, including the liver. This finding was recently corroborated in the mouse (Tremblay and Zaret, 2005). This suggest that the AIP is not only an area where lateral tissues meet as originally suggested by $\mathrm{His}$ (His, 1874) but functions as a zipper in which material from the AIP is deposited along the ventral midline as previously proposed by (Robinson, 1903) (Funccius, 1909) (Frazer, 1916) (Ludwig, 1919). Whether this material corresponds to cells endowed with high proliferation remains to be determined. If cells are deposited all along the ventral midline they will eventually colonize different axis levels although they originate from the same position. During AIP or CIP progression, they must acquire a pattern that is similar to that of the dorsal cells of the same level which derive from midline endoderm and have roughly maintained their position relative to the notochord and neural tube. In Xenopus, as the suprablastoporal lip of the blastopore forms the dorsal gut tube and the subblastoporal lip forms its ventral aspect, A-P identity also needs to be coordinated (Keller, 1975, Keller, 1976, Nieuwkoop, 1997). In Zebrafish, organ domains are segregated prior to gut tube formation (Wallace and Pack, 2003). The tube forms through the reorganization of cells that become polarized and form a lumen. This happens in the intestines first and much later in the pharynx and esophagus.

An interesting observation relative to the signals exchanged by endoderm and mesoderm (see below) is the fact that the endoderm slides posteriorly on the mesoderm (Fig. 3). For instance, N. Le Douarin showed that carbon particles put through the 3 germ layers at the level of somite 2 end up in the neck in the neural tube, at the level of the larynx in mesoderm and more posteriorly in brunchi in endoderm (Le Douarin, 1964; Tremblay and Zaret, 2005). This general posterior sliding of endoderm relative to mesoderm and mesoderm relative to neurectoderm is more pronounced posteriorly and laterally (Catala et al., 1996, Le Douarin, 1964a). Accordingly, at the molecular level, anterior boundaries of Hox genes are more rostral in the neurectoderm, then somites, then lateral plate, then endoderm (Fig. 3) (Burke et al., 1995). A shift in the same direction has been reported between ectoderm and visceral mesoderm in Drosophila (Tremml and Bienz, 1989).

In addition to these movements, Smith and Tabin (Smith and Tabin, 2000) showed that mesodermal cells migrate individually before 13-somite-stage and can thus clonally contribute to different gut organs. After this stage, although clones can populate different radial layers, they are restricted to one organ.

\section{The mesoderm sends permissive signals to endoderm}

Cultured alone, the endoderm survives very poorly (Le Douarin and Bussonnet, 1966, Okada, 1953, Okada, 1954a, Okada, 1954b, Sumiya and Mizuno, 1974, Takata, 1960). Of the few cases where culture of endoderm alone was performed it was either very short term (Kumar et al., 2003, Wells and Melton, 


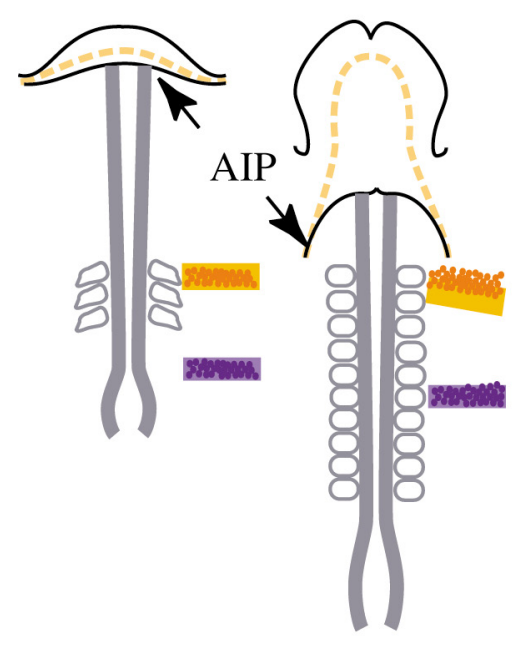

Fig. 3. Morphogenetic movements during gut tube closure in chick. Schematized ventral views of 3-somite, 10-somite, 20-somite and 28-somite embryos as well as an embryo which has completed gut tube closure at the end of somitogenesis. The anterior intestinal portal (AIP) forms at the beginning of somitogenesis and the caudal intestinal portal (CIP) at about 28-somite stage. Their progression towards the middle of the embryo closes the gut tube delineated by

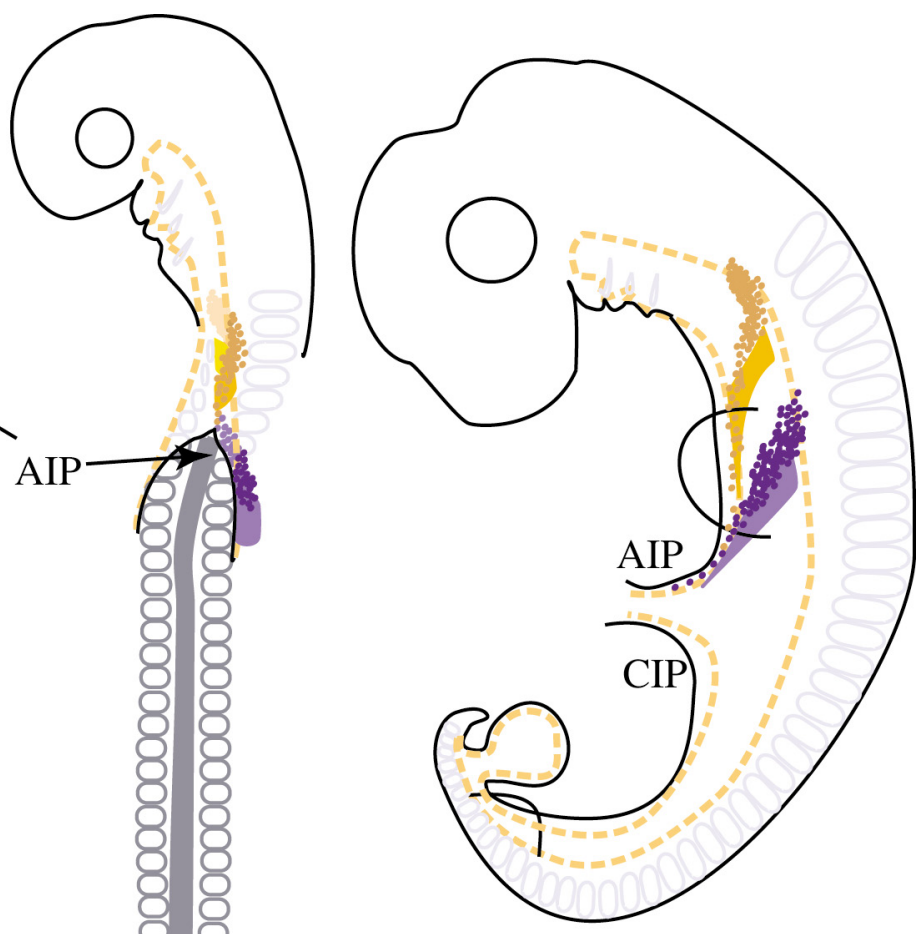
yellow lines. The endoderm at the level of somite 1 is marked by light

orange fill. Dark orange dots represent the lateral plate mesoderm from the same level. Somite 6 level is similarly labelled: light purple fill for endoderm and dark purple dots for mesoderm. The enhanced posterior shift of more lateral tissues is seen for endoderm and mesoderm as well as the enhanced posterior shift of endoderm relative to somites and mesoderm. As a result endoderm from a given A-P location contributes to different organs. The same is true for mesoderm. Moreover, endoderm and mesoderm of the same A-P origin end-up in different positions.

2000) or a few mesenchymal cells were later reported to be present in the culture (Gualdi et al., 1996) (Rossi et al., 2001). Apart from Sumiya and Mizuno (1974) who reported its culture wrapped in vitelline membrane, it is usually cultured in the presence of mesenchyme or in chorioallantoic grafts (Butler, 1935, Le Douarin, 1964a). Heterologous splanchnic mesenchyme generally allows survival and even proper differentiation but limb bud, somitic or cephalic mesoderm are poor substitutes (Le Douarin, 1964a, Le Douarin and Bussonnet, 1966, Le Douarin and Wolff, 1967). The molecular nature of some of the signals produced locally by splanchnic mesoderm has recently been uncovered. Early experiments by Nicole Le Douarin (Le Douarin, 1964a, Le Douarin, 1964b, Le Douarin, 1964c) showed that signals form the mesoderm of the heart are necessary to induce liver development. The presumptive territory of the liver, the AIP, transplanted in other mesodermal territories can develop autonomously after 6 somite-stage but requires the presence of cardiac mesoderm before this stage. As cardiac mesoderm does not induce liver when combined with other endoderm areas, these signals are permissive rather than instructive (Le Douarin, 1975). These properties were recently confirmed in the mouse (Gualdi et al., 1996). It appears that in the mouse, in the absence of cardiac mesoderm, the endoderm of the AIP expresses pancreatic markers (Deutsch et al., 2001). FGF1 and FGF2, which are expressed in the cardiac mesoderm can induce liver markers in the AIP and soluble FGF receptor forms that exert dominant negative effects block liver induction by cardiac mesoderm. It was recently suggested that FGFs sent by the cardiac mesoderm are also required for lung development (Serls et al., 2005) and that they may play an instructive role as different concentrations induce different organ markers. The septum transversum, another lateral plate mesoderm (LPM) derivative, participates in liver induction (Rossi et al., 2001)and later maintenance (Le Douarin, 1963, Le Douarin, 1964a, Le Douarin, 1964c). It produces BMPs. Exposure to noggin, a BMP inhibitor, blocks the convergent ability of cardiac mesoderm and septum transversum to induce liver markers.

At later developmental stages, LPM-derived signals are known to be essential for the maintenance of $P d x 1$ expression in the endoderm of the pancreas. Mice mutant in /s/1 (Ahlgren et al., 1997) and $N$-cadherin (Esni et al., 2001; Edsbagge et al., 2005), two genes expressed in the LPM, do not exhibit LPM convergence around the dorsal pancreas and show a sharp downregulation of $P d x 1$ expression as well as an arrest of organ development after initial budding has occurred. FGF10, a gene expressed in the mesenchyme around the pancreatic buds from the initiation of budding onward is required for the maintenance of $P d x 1$ expression (Bhushan et al., 2001).

In addition to the LPM, two mesodermal components in contact with endoderm provide permissive signals. The notochord, was shown to be required and sufficient for induction of pancreatic endocrine and exocrine markers in the 10-somite-stage presumptive pancreas endoderm (Kim et al., 1997). It sends 
permissive signals since it can not induce pancreas markers in more posterior endoderm. FGF2 and activin have been shown to mimic notochord signals but it is not known whether they are involved in vivo (Hebrok et al., 1998). Although ActRIIB ${ }^{-/-}$and ActRIIA $^{+/-} \mathrm{B}^{-/-}$mutants exhibit an anterior transformation of the posterior stomach, it is unclear whether this effect is due to the reception of notochord signals (Kim, 2000). Indeed, the exocrine pancreas is not affected in these mutants although the notochord also controls exocrine pancreas induction. In addition, the LPM around the pancreas is modified in these mutants. It is not known whether the notochord also sends permissive signals in other regions of the gut and plays a general role in dorso-ventral patterning of the endoderm. Blood vessel endothelium is also required for proper differentiation of the dorsal pancreas and liver (Lammert et al., 2001, Matsumoto et al., 2001). In the case of the liver, initial specification happens normally in the absence of endothelial cells but liver cells fail to proliferate and invade septum transversum mesenchyme (Matsumoto et al., 2001). As for the pancreas, the aorta is required for differentiation of endocrine cells and morphogenesis of the dorsal pancreatic bud (Lammert etal., 2001; Yoshitomi and Zaret, 2004). Recent evidence suggests that the vitteline veins which are close to the ventral pancreatic bud are not required for ventral bud initiation (Yoshitomi and Zaret, 2004). It is possible that this association is also important for other digestive organs which also exhibit an early association with endothelial cells (Matsumoto et al., 2001). It is not clear whether any endothelial cells have this inductive capacity.

\section{Lateral plate mesoderm located at different A-P positions sends different instructive information to endoderm}

In Drosophila, the endoderm (midgut) is patterned by regionalized signals originating from the mesoderm (Bienz, 1994, Bienz, 1997). In Vertebrates, there is a long lasting cross talk between endoderm and mesoderm that can be illustrated on the example of the liver and heart. It has been observed very early that these two organs develop together (Hunt, 1932, Willier and Rawles, 1931). Soon after gastrulation anterior endoderm but not posterior endoderm sends signals that induce cardiomyocytes in mesodermal cells that exit the streak (Schultheiss et al., 1997, Schultheiss et al., 1995). Wnt-inhibitors expressed in anterior endoderm block the heart-repressing activity of posterior Wnts (Marvin etal., 2001, Tzahor and Lassar, 2001; Foley and Mercola,

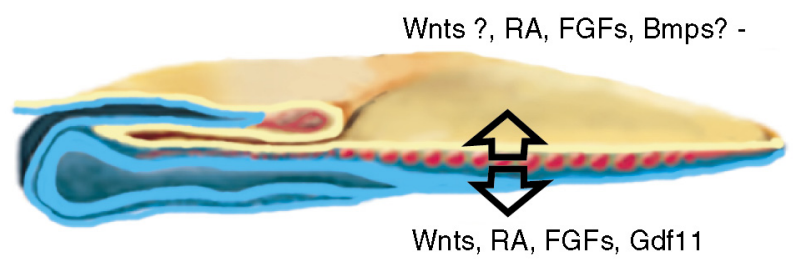

Fig. 4. The mesoderm coordinates A-P patterning in the three germ layers. A-P patterning of endoderm and neurectoderm is under the control of mesodermal signals. RA and FGFs pattern the two germ layers. Although Wnts play a role in A-P patterning of the neural tube questions remain about the time of action and about its role in endoderm. TGF $\beta$ family members are involved in patterning both layers but the mechanism and precise members involved need to be better characterized.
2005; Schneider and Mercola, 2001). At early somite stages, the heart signals back to endoderm to induce hepatocytes as described above. Later, the septum transversum is required for liver outgrowth. This and other examples lead to the conclusion that positional information in the digestive tract is neither carried by endoderm nor mesoderm but that both carry partial information which varies with time (Yasugi, 1993).

It is still unclear whether there is a general patterning scheme of endoderm that coordinates the whole A-Paxis. We recently showed that at somitic stages, when many positional markers are induced in endoderm, the LPM sends instructive signals to the endoderm layer at least from the duodenum to posterior small intestine (Kumar et al., 2003). In the absence of LPM, the endoderm retains a native endodermal state but does not turn on or retain positional markers (Horb and Slack, 2001, Kumar et al., 2003). It retains its original A-P identity when associated with more anterior endoderm but it is repatterned when associated with more posterior LPM. This is very similar to the patterning mechanism of the neural tube at the same stage as it has been shown that somites and Hensen's node can induce more posterior but not more anterior fates (Grapin-Botton et al., 1997, Itasaki et al., 1996, Liu et al., 2001, Muhr et al., 1997). The somites share with the LPM the ability to induce posterior markers in endoderm (Kumar etal., 2003). This suggests that the mesoderm coordinates the patterning of all three germ layers (Fig. 4). As in the neural tube Hensen's node also sends posteriorizing signals as late as somitic stages, it will be interesting to see whether the node also plays such a late role in endoderm patterning (Liu et al., 2001). Plasticity at equivalent stages had been observed in frogs where stage 22-25 but not stage 28 endoderm looses $X / h b o x 8 / P d x 1$ expression when associated to posterior mesoderm (Zeynali et al., 2000). A gradient of signaling along the A-P axis is compatible with the observations of Nicole Le Douarin who grafted the liver endodermal primordium after 6-somite-stage in splanchnopleura and showed that the more posterior the graft the less liver epithelial cords developed (Le Douarin, 1963, Le Douarin, 1964c). It is also in agrrement with the observation that small intestine endoderm loses very early its ability to be repatterned when associated with mesenchyme from other regions (Andrew and Rawdon, 1990, Gumpel-Pinot et al., 1978, Yasugi, 1993, Yasugi and Mizuno, 1978, Yasugi et al., 1991). It is still unclear whether the posterior dominance of mesoderm observed here holds true along the entire A-P axis as already a few discrepancies are found in the literature. The floor of the pharynx, grafted in the splanchnopleure at similar stages and later found in the small intestinal wall or in the body wall, forms thyroid, thymus, muscular and glandular stomach, liver, exocrine pancreas and intestine (Le Douarin and Bussonnet, 1966, Le Douarin and Wolff, 1967). The anterior marker Sox2 (Fig. 2) is induced in small intestine until E4 (equivalent to $11.5 \mathrm{dpc}$ in the mouse) (Ishii et al., 1998).

Plasticity seems to be lost long before birth. Ishii and colleagues showed that the stomach epithelium is posteriorized by small intestine epithelium until E4 (equivalent to $11.5 \mathrm{dpc}$ in the mouse) but at E6 (about $12.5 \mathrm{dpc}$ ) although signals are still produced by the mesenchyme, the endoderm has lost its ability to express the intestinal markers $C d x A$ and sucrase (Ishii et al., 1997, Ishii et al., 1998) (Haffen et al., 1982, Ishizuya-Oka and Mizuno, 1984). In agreement, $14.5 \mathrm{dpc}$ stomach or lung epithelium do not appear to be influenced by small intestine mesenchyme (Duluc etal., 1994). 
The mesenchymal signals seem to perdure after the loss of plasticity (Ishii et al., 1997). It is not always clear whether the signals identified pertain to general A-P patterning or to local events. For instance, stomach glands can develop in many epithelia including posterior small intestine until late stages (E9). In this case the glandular structure forms but it does not express pepsinogen and it retains sucrase (Takiguchi-Hayashi and Yasugi, 1990, Yasugi et al., 1985). Information to generate the structure is in the mesenchyme but A-P information may reside in the epithelium. In this case, the muscular stomach mesenchyme mixed 1:9 with glandular stomach mesenchyme blocks the ability to induce glands even if muscular stomach clls are far from the epithelium, thus suggesting local repressive secreted signals acting at a distance (Urase and Yasugi, 1993).

A-P identity in paraxial mesoderm is coupled with segmentation and determined once somites are formed (Dubrulle et al., 2001, Kieny et al., 1972, Nowicki and Burke, 2000, Zakany et al., 2001). There is probably later plasticity of A-P identity in somatopleure since when an additional limb is induced by application of FGFloaded beads between the wing and leg Hox gene expression in somatopleure is either shifted posteriorly to ressemble the wing pattern or shifted anteriorly to match the leg pattern (Cohn et al., 1997). Moreover the LPM environment changes A-P identity in isolated somitic cells that migrate into the LPM to form limb muscle (Nowicki and Burke, 2000). Nothing such is known about the splanchnopleure.

\section{Molecular basis of endoderm A-P patterning}

\section{Retinoic acid induces posterior character in endoderm as in neurectoderm}

In the neural tube, FGFs (Cox and Hemmati-Brivanlou, 1995; Kengaku and Okamoto, 1995; Lamb and Harland, 1995; Mathis, et al., 2001; Storey, et al., 1998), Wnts (Erter, et al., 2001; Mcgrew, et al., 1997; Nordstrom, et al., 2002) and retinoic acid (RA) (Maden, 1999) are known to induce posterior fates in a graded manner (Bel-Vialar, et al., 2002; Liu, et al., 2001). More recently, the TGF $\beta$ family Growth/Differentiation Factor GDF11, was also proposed to be responsible for the induction of the most posterior fates, in conjunction with FGFs (Liu, et al., 2001; Mcpherron, et al., 1999).

As in the neural tube, RA has posteriorizing effects on the endoderm. At gastrulation stages in the chick it is able to repress the anterior marker Otx2(Bally-Cuif, et al., 1995). The role of RA in endoderm organ formation has been reported in Zebrafish, Xenopus, mouse and chick (Chen, et al., 2004; Kumar, et al., 2003; Molotkov, et al., 2005; Stafford, et al., 2004; Stafford and Prince, 2002). These publications focused largely on the pancreas and showed that retinoic acid is important at gastrulation stages to induce this organ and to control the balance between endocrine and exocrine cells. Although analyzed in less detail, two of these publications suggest that RA controls endoderm organ position along the A-P axis as it does in the neural tube. In Zebrafish, RA induces an anterior shift in endoderm gene expression throughout the foregut (down to duodenum/pancreas) and blocking the pathway prevents induction of the most posterior fates (Stafford and Prince, 2002). In chick, Kumar et al. (Kumar, et al., 2003) observed that RA induces $P d \times 1$, a pancreato-duodenal marker in the stomach/esophagus, but also extends expression of $C d x A$, a small and large intestine marker as anterior as the esophagus. However, the effects described in the chick occur at much later stages, when somites have formed. Although the requirement for RA in endoderm patterning has not been addressed in this study, it is clear that endoderm still responds to RA at 10-somite-stage unlike in fish and Xenopus. Many A-P markers of endoderm are induced at this stage. It also controls A-P patterning of endoderm in Amphioxus (Escriva, et al., 2002; Schubert, et al., 2005), but these studies contradict previous findings showing that in Xenopus, RA does not affect the expression of the pancreatic marker Pdx1 after treatment of whole embryos at stage 12 and 25 (Zeynali and Dixon, 1998). The late action of RA in chick is consistent with a posterior to anterior gradient of RA proposed to be present in chick LPM at the 10-somite stage (Swindell, et al., 1999). Indeed, Raldh2, an enzyme responsible for RA synthesis is expressed in the streak and later in somites and trunk LPM, tissues that have a posteriorizing activity. RA is thus synthesized only in the trunk. Cyp26, an enzyme responsible for $R A$ degradation and often expressed in tissues that respond to RA is in lateral endoderm. Its expression forms a gradient at stage 14, with high expression at the level of the first somite and going down towards somite 15. The amount of signal received posteriorly may thus be higher due to lower degradation rates. (Blentic, et al., 2003). It is not clear whether RA patterns the endoderm all along the axis. In the neural tube RA only plays a role in regulating genes from the hindbrain (pharynx level) to the cervical level (Hoxc-6). It downregulates more posterior Hox genes in vivo and in vitro (Bel-Vialar, et al., 2002; Liu, et al., 2001; Simeone, et al., 1991). In endoderm, RA appears to induce the caudal homologue $C d x A$ in the chick and not to affect it in Zebrafish (Kumar, et al., 2003; Stafford and Prince, 2002). In each of these cases it is unclear if RA is acting directly upon the endoderm, or indirectly via the mesoderm. The best evidence for direct action of RA upon the endoderm has been provided by investigating the Hoxb1 promoter, which is regulated by RA in endoderm and ectoderm through two different promoter elements (Huang, et al., 2002; Huang, et al., 1998). No such elements have been identified in the $P d x 1$ or $C d x A / 1$ promoters. This pathway may interact with the FGF pathway in endoderm during gastrulation as the FGF pathway regulates the expression of RA receptors and of enzymes that control RA synthesis and degradation (Shiotsugu, etal., 2004) and conversely RA signaling regulates FGF receptor expression.

\section{FGFs and Wnts, posterior inducers in the nervous system may act on endoderm patterning}

In the nervous system at somite stages, RA is responsible for pattern formation at the level of the hindbrain and cervical level. More posteriorly, Hox gene expression is induced by FGFs (mainly 2 and 4 and much less efficiently 8) that act partially through Cdxs (Bel-Vialar et al., 2002; Charite et al., 1998; Liu, et al., 2001). In mouse endoderm, FGF4 (but not FGF2, 5 or 8) applied to anterior endoderm of late gastrulas (7.5 dpc) induces markers that are characteristic for the posterior half of the embryo. FGF4 is expressed in the posterior primitive streak and later in the tail bud (Niswander and Martin, 1992). Embryos knockout for Fgf4 arrest before gastrulation (Feldman et al., 1995) and therefore the requirement for FGF4 in A-P patterning has not been tested. As in the nervous system, FGF2 and 4 are the most potent posterior 
inducers. Our recent experiments suggest that FGFs also function later to pattern the mid-hindgut (Dessimoz et al., unpublished). FGFs may have a permissive action and maintain cells in a state of responsiveness to other signals (Mathis et al., 2001; Nordstrom et al., 2002). FGF response elements that bind ets transcription factors (downstream targets of FGFs) have been recently evidenced in $X c a d 3(C d \times B)$ promoter in Xenopus. $C d \times B$ may thus be a direct endoderm target of FGF signaling (Haremaki et al., 2003). $P d x 1$ may also be a direct target of the FGF4 signaling.

Wnts, in the presence of FGFs, play a role in A-P patterning of the nervous system (Holland, 2002; Mcgrew et al., 1997; Nordstrom et al., 2002). Wnt8 is expressed in the caudal paraxial mesoderm in gastrulating and headfold stage embryos and activates posterior markers in a graded manner on isolated neural tube. It is not clear whether it keeps signaling at later stages. Wnt3A is expressed in the tail bud, as is wnt8 in a subset of Vertebrates (Holland, 2002). $C d \times 1 / A$ is a direct target of canonical Wnt signaling that is important for induction of this gene in primitive streak, somites (wnt3A) and possibly endoderm (Ikeya and Takada, 2001; Lickert et al., 2000; Lickert and Kemler 2002). There may be a feedback loop as $C d x B$, a chick caudal gene can induce $W n t 8 c$ when misexpressed in the heart (Ehrman and Yutzey, 2001). Since $C d x 1$ is induced late during development in the endoderm ( $14 \mathrm{dpc})$ it would be interesting to know whether induction of earlier endodermal markers is also dependant on Wnt signaling. None of the isolated $C d x 1$ promoter elements including those with Wnt pathway target sites drive endodermal expression (Lickert and Kemler, 2002).

It is of interest that in $C$. elegans, all but one division in the $\mathrm{E}$ lineage occur along the A-P axis. These divisions are asymmetric such that only the anterior cell inherits the Tcf-related protein POP1 (Lin et al., 1998). In the first asymetric cleavage of EMS that generates the endodermal precursor E posteriorly, this is due to the production of the MOM-2 Wnt ligand by the P2 posterior cell (Lin et al., 1998). Later divisions require MOM-5/Frizzled but not MOM-2/ Wnt (Park and Priess, 2003). In Drosophila, Wingless is secreted by the mesoderm surrounding the endoderm where it induces labia/and later copper cells at low levels while closer to its site of production it represses labial and induces the differentiation of large flat cells (Hoppler and Bienz, 1995).

\section{A role for BMPs in endoderm A-P patterning: differences between endoderm and neurectoderm?}

In Drosophila, Hox genes are regionally expressed in the mesoderm and control the local secretion of Decapentaplegic (Dpp). Dpp is expressed in a specific band in the midgut mesoderm, next to $\mathrm{Wg}$. It regulates Hox gene expression in mesoderm and endoderm (Immergluck et al., 1990, Staehling-Hampton and Hoffmann, 1994, Staehling-Hampton et al., 1994, Tremml and Bienz, 1989)(Tremml and Bienz, 1989; Immergluck et al.,1990; (Panganiban et al., 1990). Expression of labial in endoderm depends on cooperation of Hox binding sites that bind labial and DPP responsive elements (Marty et al., 2001). LEF1 and DPP/mad binding sites in ultrabithorax promoter directly control this gene (Riese et al., 1997).

In Vertebrates, we showed that BMP2, 4 and 7 as well as activin expand $P d x 1$ and $C d x A$ expression anteriorly in endoderm (Kumar et al., 2003). In addition noggin and follistatin block induction of posterior genes elicited by LPM, suggesting that a $\mathrm{BMP}$ rather than activin is implicated (activin is not blocked by noggin). As we have discussed that during the morphogenesis of the gut more lateral endoderm eventually contributes to more posterior tissue, it is possible that the effect of BMPs is a lateral transformation. In Zebrafish, Tiso et al. (Tiso et al., 2002) have demonstrated that $s w i r l(B M P 2 b)$ mutants have a general reduction in posterior endoderm identities. On the contrary, chordino mutants have expanded posterior gut and reduced anterior digestive tract. Although the effect of BMP2b appears to be very early in fish since the expression of the hairy gene her5 in anterior endoderm was affected in swirl and chordino mutants at $80 \%$ epiboly (late gastrulation), it has been shown that activin does not posteriorize $7.5 \mathrm{dpc}$ mouse endoderm (gastrulation). There may be a difference of timing in A-P patterning in these two species as seen before for retinoic acid (Wells and Melton, 2000). The two first publications show that these ligands are able to induce gene expression characteristic of multiple regions along the A-P axis and are thus likely to act in a graded manner although this has not been demonstrated yet. One would then expect to see a graded expression of one or several BMPs or activin along the A-P axis at the stages studied here. Indeed, the LPM adjacent to the presomitic mesoderm strongly expresses BMP4 with expression becoming progressively weaker in the LPM adjacent to fully-segmented somites (Pourquie et al., 1996, Reshef etal., 1998, Schultheiss and Lassar, 1997) (our unpublished results). In addition, the expression of multiple BMPs has been reported in the mesenchyme surrounding the endoderm (Roberts et al., 1995, Smith et al., 2000, Solloway and Robertson, 1999, Winnier etal., 1995) while the BMP receptors $B M P R I A$ and BMPRI/ are expressed in endoderm (Mishina et al., 1995, Roelen et al., 1997). Activin receptor II inactivation in the mouse reveals a requirement for these receptors in A-P patterning in the foregut (Kim et al., 2000). Since Gdf11 plays a role in posterior gene induction in the neural plate it would be interesting to see if a GDF is involved in posteriorization of endoderm (Liu et al., 2001, McPherron et al., 1999).

Roberts et al. (Roberts et al., 1995) showed that Shh induces Hox genes in the posterior hindgut. Shh is initially expressed in the endoderm of the CIP when the gut folds and later on spreads to most of the gut tube. Precocious activation of Shh in the gut mesoderm induces an anterior shift of Hoxd11 and Hoxd13 expression in mesoderm. This shift is limited since regions anterior to the yolk stalk are not competent to express these genes at this stage. It is not clear how Shh action is restricted as this gene is expressed in the AIP where it does not induce posterior Hox genes. Since Shh also induces BMPs in the mesoderm, the ability of Shh to induce posterior genes may be relayed by BMPs.

\section{Conclusion}

Beyond characterizing the interactions between the retinoic acid, Wnt, FGF and BMP pathways in endoderm patterning, new directions of research may go towards further characterization of endoderm-mesoderm interactions in light of the sliding movements observed by Nicole Le Douarin. Fate mapping the AIP with modern techniques should in particular solve the question as to whether single cells of the AIP can contribute to different organs.

The control of A-P identity in endodermal cells is important not only during development but must be maintained in the adult. The 
loss of identity leads to metaplasia which often evolve in neoplasia. Mice which have lost one copy of $C d x 2$ in their genome develop adenomatous polyps, mostly in the proximal colon (Beck et al., 2003, Beck et al., 1999, Chawengsaksophak et al., 1997). These polyps contain areas were $C d \times 2$ is not expressed although there is no loss of heterozygosity. These $C d \times 2$-negative domains show a continuous sequence of all digestive tract epithelia from colon to esophagus suggesting a gradient of signaling. Dysplasia is observed in $20 \%$ of lesions. Although $C d \times 2$ expression is often lost in colon cancer, it is rarely mutated (da Costa et al., 1999, Mallo etal., 1997, Yagi et al., 1999). Another example of induced metaplasia mimics a human affection. When $C d x 2$ is ectopically activated in the stomach, intestinal metaplasia is induced (Silberg et al., 2002). $C d \times 2$ expression is observed in most gastric intestinal metaplasia and gastric carcinoma (Almeida et al., 2003, Bai et al., 2002, Seno et al., 2002). In the esophagus, $10 \%$ of Barrett metaplasia, which consist in gastric tissue in the esophagus, evolve in esophagal cancer (OMIM 109350). The role of $C d x$ up- or down-regulation in the evolution to neoplasia and the factors that cause it are interesting questions for the future. In particular, since the mesenchyme controls $C d x$ expression during development, the role of the stroma would be worth investigating.

\section{Aknowledgements}

The author thanks Sophie Cherpillod for her help with the bibliography. Particular thanks are devoted to Nicole Le Douarin who transmitted her long-lasting passion for biology and her integrative vision in which classical and modern biology as well as many model systems have their place.

\section{References}

AHLGREN, U., PFAFF, S.L., JESSELL, T.M., EDLUND, T. and EDLUND, H. (1997). Independent requirement for isl 1 in formation of pancreatic mesenchyme and islet cells. Nature 385: 257-60.

ALEXANDER, J. and STAINIER, D.Y. (1999). A molecular pathway leading to endoderm formation in zebrafish. Curr Biol 9: 1147-57.

ALMEIDA, R., SILVA, E., SANTOS-SILVA, F., SILBERG, D.G., WANG, J., DE BOLOS, C. and DAVID, L. (2003). Expression of intestine-specific transcription factors, $c d \times 1$ and cdx2, in intestinal metaplasia and gastric carcinomas. $J$ Patho/ 199: 36-40.

ANDREW, A. and RAWDON, B.B. (1990). Intestinal mesenchyme provokes differentiation of intestinal endocrine cells in gizzard endoderm. Differentiation 43: 165-74

ANG, S.L., CONLON, R.A., JIN, O. and ROSSANT, J. (1994). Positive and negative signals from mesoderm regulate the expression of mouse otx2 in ectoderm explants. Development 120: 2979-89.

ANG, S.L. and ROSSANT, J. (1994). Hnf-3 beta is essential for node and notochord formation in mouse development. Cell 78: 561-74.

ANG, S.L., WIERDA, A., WONG, D., STEVENS, K.A., CASCIO, S., ROSSANT, J. and ZARET, K.S. (1993). The formation and maintenance of the definitive endoderm lineage in the mouse: Involvement of hnf3/forkhead proteins. Development 119: 1301-15.

AUBIN, J., CHAILLER, P., MENARD, D. and JEANNOTTE, L. (1999). Loss of hoxa5 gene function in mice perturbs intestinal maturation. Am J Physio/ 277: C965-73.

AUBIN, J., DERY, U., LEMIEUX, M., CHAILLER, P. and JEANNOTTE, L. (2002). Stomach regional specification requires hoxa5-driven mesenchymal-epithelial signaling. Development 129: 4075-87.

AUBIN, J., LEMIEUX, M., TREMBLAY, M., BERARD, J. and JEANNOTTE, L. (1997). Early postnatal lethality in hoxa- 5 mutant mice is attributable to respiratory tract defects. Dev Biol 192: 432-45.

BAI, Y.Q., YAMAMOTO, H., AKIYAMA, Y., TANAKA, H., TAKIZAWA, T., KOIKE, M., KENJI YAGI, O., SAITOH, K., TAKESHITA, K., IWAI, T. et al. (2002). Ectopic expression of homeodomain protein cdx2 in intestinal metaplasia and carcinomas of the stomach. Cancer Lett 176: 47-55.

BALLY-CUIF, L., GOUTEL, C., WASSEF, M., WURST, W. and ROSA, F. (2000). Coregulation of anterior and posterior mesendodermal development by a hairyrelated transcriptional repressor. Genes Dev 14: 1664-77.

BALLY-CUIF, L., GULISANO, M., BROCCOLI, V. and BONCINELLI, E. (1995). Cotx2 is expressed in two different phases of gastrulation and is sensitive to retinoic acid treatment in chick embryo. Mech Dev 49: 49-63.

BECK, F., CHAWENGSAKSOPHAK, K., LUCKETT, J., GIBLETT, S., TUCCI, J., BROWN, J., POULSOM, R., JEFFERY, R. and WRIGHT, N.A. (2003). A study of regional gut endoderm potency by analysis of cdx2 null mutant chimaeric mice. Dev Biol 255: 399-406.

BECK, F., CHAWENGSAKSOPHAK, K., WARING, P., PLAYFORD, R.J. and FURNESS, J.B. (1999). Reprogramming of intestinal differentiation and intercalary regeneration in cdx2 mutant mice. Proc Natl Acad Sci USA 96: 7318-23.

BECK, F., TATA, F. and CHAWENGSAKSOPHAK, K. (2000). Homeobox genes and gut development. Bioessays 22: 431-41.

BELLAIRS, R. (1953). Studies on the development of the foregut in the chick blastoderm. 2. The morphogenetic movements. J. Embryol. Exp. Morphol. 1: 369385.

BELO, J.A., BOUWMEESTER, T., LEYNS, L., KERTESZ, N., GALLO, M., FOLLETTIE, M. and DE ROBERTIS, E.M. (1997). Cerberus-like is a secreted factor with neuralizing activity expressed in the anterior primitive endoderm of the mouse gastrula. Mech. Dev. 68: 45-57.

BEL-VIALAR, S., ITASAKI, N. and KRUMLAUF, R. (2002). Initiating hox gene expression: In the early chick neural tube differential sensitivity to fgf and ra signaling subdivides the hoxb genes in two distinct groups. Development 129: 5103-15.

BHUSHAN, A., ITOH, N., KATO, S., THIERY, J.P., CZERNICHOW, P., BELLUSCI, S. and SCHARFMANN, R. (2001). Fgf10 is essential for maintaining the proliferative capacity of epithelial progenitor cells during early pancreatic organogenesis. Development 128: 5109-17.

BIBEN, C., STANLEY, E., FABRI, L., KOTECHA, S., RHINN, M., DRINKWATER, C. LAH, M., WANG, C.C., NASH, A., HILTON, D. et al. (1998). Murine cerberus homologue mcer-1: A candidate anterior patterning molecule. Dev. Biol. 194: 13551.

BIENZ, M. (1994). Homeotic genes and positional signalling in the drosophila viscera Trends Genet 10: 22-6.

BIENZ, M. (1997). Endoderm induction in drosophila: The nuclear targets of the inducing signals. Curr Opin Genet Dev 7: 683-8.

BLENTIC, A., GALE, E. and MADEN, M. (2003). Retinoic acid signalling centres in the avian embryo identified by sites of expression of synthesising and catabolising enzymes. Dev Dyn 227: 114-27.

BLUM, M., GAUNT, S.J., CHO, K.W., STEINBEISSER, H., BLUMBERG, B., BITTNER, D. and DE ROBERTIS, E.M. (1992). Gastrulation in the mouse: The role of the homeobox gene goosecoid. Cell 69: 1097-106.

BOULET, A.M. and CAPECCHI, M.R. (1996). Targeted disruption of hoxc-4 causes esophageal defects and vertebral transformations. Dev Biol 177: 232-49.

BROOKE, N.M., GARCIA-FERNANDEZ, J. and HOLLAND, P.W. (1998). The parahox gene cluster is an evolutionary sister of the hox gene cluster. Nature 392: 920-2.

BURKE, A.C., NELSON, C.E., MORGAN, B.A. and TABIN, C. (1995). Hox genes and the evolution of vertebrate axial morphology. Development 121: 333-46.

BUTLER, E. (1935). The developmental capacity of regions of the unincubated chick blastoderm as tested in chorio-allantoic grafts. J. Exp. Zool. 70: 387-388.

CATALA, M., TEILLET, M.A., DE ROBERTIS, E.M. and LE DOUARIN, M.L. (1996). A spinal cord fate map in the avian embryo: While regressing, hensen's node lays down the notochord and floor plate thus joining the spinal cord lateral walls. Development 122: 2599-610.

CHAPMAN, S.C., SCHUBERT, F.R., SCHOENWOLF, G.C. and LUMSDEN, A (2002). Analysis of spatial and temporal gene expression patterns in blastula and gastrula stage chick embryos. Dev Biol 245: 187-99.

CHARITE, J., DE GRAAFF, W., CONSTEN, D., REIJNEN, M.J., KORVING, J. and DESCHAMPS, J. (1998). Transducing positional information to the hox genes: Critical interaction of $c d x$ gene products with position-sensitive regulatory elements. Development 125: 4349-58. 
CHAWENGSAKSOPHAK, K., JAMES, R., HAMMOND, V.E., KONTGEN, F. and BECK, F. (1997). Homeosis and intestinal tumours in cdx2 mutant mice. Nature 386: 84-7.

CHEN, Y., PAN, F. C., BRANDES, N., AFELIK, S., SOLTER, M. and PIELER, T. (2004). Retinoic acid signaling is essential for pancreas development and promotes endocrine at the expense of exocrine cell differentiation in Xenopus. Dev Bio/271: 144-160.

COHN, M.J., PATEL, K., KRUMLAUF, R., WILKINSON, D.G., CLARKE, J.D. and TICKLE, C. (1997). Hox9 genes and vertebrate limb specification. Nature 387: 97101.

COX, W.G. and HEMMATI-BRIVANLOU, A. (1995). Caudalization of neural fate by tissue recombination and bfgf. Development 121: 4349-58.

DA COSTA, L.T., HE, T.C., YU, J., SPARKS, A.B., MORIN, P.J., POLYAK, K., LAKEN, S., VOGELSTEIN, B. and KINZLER, K.W. (1999). Cdx2 is mutated in a colorectal cancer with normal apc/beta-catenin signaling. Oncogene 18: 5010-4.

DE SANTA BARBARA, P. and ROBERTS, D.J. (2002). Tail gut endoderm and gut/ genitourinary/tail development: A new tissue-specific role for hoxa13. Development 129: 551-61.

DEUTSCH, G., JUNG, J., ZHENG, M., LORA, J. and ZARET, K.S. (2001). A bipotential precursor population for pancreas and liver within the embryonic endoderm. Development 128: 871-81.

DUBRULLE, J., MCGREW, M.J. and POURQUIE, O. (2001). Fgf signaling controls somite boundary position and regulates segmentation clock control of spatiotemporal hox gene activation. Cel/ 106: 219-32.

DUFORT, D., SCHWARTZ, L., HARPAL, K. and ROSSANT, J. (1998). The transcription factor hnf3beta is required in visceral endoderm for normal primitive streak morphogenesis. Development 125: 3015-25.

DULUC, I., FREUND, J.N., LEBERQUIER, C. and KEDINGER, M. (1994). Fetal endoderm primarily holds the temporal and positional information required for mammalian intestinal development. J Cell Biol 126: 211-21.

EDSBAGGE, J., JOHANSSON, J. K., ESNI, F., LUO, Y., RADICE, G. L. and SEMB, H. (2005). Vascular function and sphingosine-1-phosphate regulate development of the dorsal pancreatic mesenchyme. Development 132: 1085-1092.

EHRMAN, L.A. and YUTZEY, K.E. (2001). Anterior expression of the caudal homologue ccdx-b activates a posterior genetic program in avian embryos. Dev Dyn 221: 412 21.

EPSTEIN, M., PILLEMER, G., YELIN, R., YISRAELI, J.K. and FAINSOD, A. (1997). Patterning of the embryo along the anterior-posterior axis: The role of the caudal genes. Development 124: 3805-14.

ERTER, C.E., WILM, T.P., BASLER, N., WRIGHT, C.V. and SOLNICA-KREZEL, L. (2001). Wnt8 is required in lateral mesendodermal precursors for neural posteriorization in vivo. Development 128: 3571-83.

ESCRIVA, H., HOLLAND, N.D., GRONEMEYER, H., LAUDET, V. and HOLLAND, L.Z. (2002). The retinoic acid signaling pathway regulates anterior/posterior patterning in the nerve cord and pharynx of amphioxus, a chordate lacking neural crest. Development 129: 2905-16.

ESNI, F., JOHANSSON, B.R., RADICE, G.L. and SEMB, H. (2001). Dorsal pancreas agenesis in n-cadherin- deficient mice. Dev Biol 238: 202-12.

FELDMAN, B., POUEYMIROU, W., PAPAIOANNOU, V.E., DECHIARA, T.M. and GOLDFARB, M. (1995). Requirement of fgf-4 for postimplantation mouse development. Science 267: 246-9.

FOLEY, A.C., STOREY, K.G. and STERN, C.D. (1997). The prechordal region lacks neural inducing ability, but can confer anterior character to more posterior neuroepithelium. Development 124: 2983-96.

FOLEY, A. C. and MERCOLA, M. (2005). Heart induction by Wnt antagonists depends on the homeodomain transcription factor Hex. Genes Dev19: 387-396.

FRAZER, J.E. (1916). On the development of the structures associated with the roof of the primitive mouth. Hunterian lecture. The Lancet 2: 45-53.

FUNCCIUS, T. (1909). Der prothorax der Vögel und Saüger. Morph. Jahrb. 39: 370445.

GAERTNER, R.A. (1949). Development of the posterior trunk and tail of the chick embryo. J. Exp. Morphol. 111: 157-174.

GASSER, E. (1880). Die entstehung der cloakenöffnung bei Hühnerembryonen. Arch. Anat. Entwickl. Jahrgang 1880: 297-319.
GLINKA, A., WU, W., DELIUS, H., MONAGHAN, A.P., BLUMENSTOCK, C. and NIEHRS, C. (1998). Dickkopf-1 is a member of a new family of secreted proteins and functions in head induction. Nature 391: 357-62.

GRAPIN-BOTTON, A., BONNIN, M.A. and LE DOUARIN, N.M. (1997). Hox gene induction in the neural tube depends on three parameters: Competence, signal supply and paralogue group. Development 124: 849-59.

GRAPIN-BOTTON, A. and MELTON, D.A. (2000). Endoderm development: From patterning to organogenesis. Trends Genet 16: 124-30.

GUALDI, R., BOSSARD, P., ZHENG, M., HAMADA, Y., COLEMAN, J.R. and ZARET, K.S. (1996). Hepatic specification of the gut endoderm in vitro: Cell signaling and transcriptional control. Genes Dev 10: 1670-82.

GUMPEL-PINOT, M., YASUGI, S. and MIZUNO, T. (1978). [Differentiation of the endodermal epithelium associated with the splanchnic mesoderm]. C R Acad SCi Hebd Seances Acad Sci D 286: 117-20.

HAFFEN, K., KEDINGER, M., SIMON-ASSMANN, P.M. and LACROIX, B. (1982). Mesenchyme-dependent differentiation of intestinal brush-border enzymes in the gizzard endoderm of the chick embryo. Prog Clin Biol Res 85 Pt B: 261-70.

HAREMAKI, T., TANAKA, Y., HONGO, I., YUGE, M. and OKAMOTO, H. (2003). Integration of multiple signal transducing pathways on Fgf response elements of the Xenopus caudal homologue Xcad3. Development 130: 4907-4917.

HATADA, Y. and STERN, C.D. (1994). A fate map of the epiblast of the early chick embryo. Development 120: 2879-89.

HEBROK, M., KIM, S.K. and MELTON, D.A. (1998). Notochord repression of endodermal sonic hedgehog permits pancreas development. Genes Dev 12: 1705-13.

HIS, W. (1874). Unsere körperform und das physiologishe problem ihrer entshehung Liepzig.

HOLLAND, L.Z. (2002). Heads or tails? Amphioxus and the evolution of anteriorposterior patterning in deuterostomes. Dev Biol 241: 209-28.

HOODLESS, P.A., PYE, M., CHAZAUD, C., LABBE, E., ATTISANO, L., ROSSANT, J. and WRANA, J.L. (2001). Foxh1 (fast) functions to specify the anterior primitive streak in the mouse. Genes Dev. 15: 1257-71.

HOPPLER, S. and BIENZ, M. (1995). Two different thresholds of wingless signalling with distinct developmental consequences in the drosophila midgut. EMBO J 14: 5016-26.

HORB, M.E. and SLACK, J.M. (2001). Endoderm specification and differentiation in xenopus embryos. Dev Biol 236: 330-43.

HUANG, D., CHEN, S.W. and GUDAS, L.J. (2002). Analysis of two distinct retinoic acid response elements in the homeobox gene hoxb1 in transgenic mice. Dev Dyn 223: 353-70.

HUANG, D., CHEN, S.W., LANGSTON, A.W. and GUDAS, L.J. (1998). A conserved retinoic acid responsive element in the murine hoxb-1 gene is required for expression in the developing gut. Development 125: 3235-46.

HUNT, T.E. (1932). Potencies of transverse levels of the chick blastoderm in the definitive streak stage. Anat. Rec. 55: 41-69.

IKEYA, M. and TAKADA, S. (2001). Wnt-3a is required for somite specification along the anteroposterior axis of the mouse embryo and for regulation of $\mathrm{cdx}-1$ expression. Mech Dev 103: 27-33.

IMMERGLUCK, K., LAWRENCE, P.A. and BIENZ, M. (1990). Induction across germ layers in drosophila mediated by a genetic cascade. Cel/ 62: 261-8.

ISAACS, H.V., POWNALL, M.E. and SLACK, J.M. (1998). Regulation of hox gene expression and posterior development by the xenopus caudal homologue xcad3. EMBO J 17: 3413-27.

ISHII, Y., FUKUDA, K., SAIGA, H., MATSUSHITA, S. and YASUGI, S. (1997). Early specification of intestinal epithelium in the chicken embryo: A study on the localization and regulation of cdxa expression. Dev Growth Differ 39: 643-53.

ISHII, Y., REX, M., SCOTTING, P.J. and YASUGI, S. (1998). Region-specific expression of chicken sox2 in the developing gut and lung epithelium: Regulation by epithelialmesenchymal interactions. Dev Dyn 213: 464-75.

ISHIZUYA-OKA, A. and MIZUNO, T. (1984). Intestinal cytodifferentiation in vitro of chick stomach endoderm induced by the duodenal mesenchyme. $J$ Embryol Exp Morphol 82: 163-76.

ITASAKI, N., SHARPE, J., MORRISON, A. and KRUMLAUF, R. (1996). Reprogramming hox expression in the vertebrate hindbrain: Influence of paraxial mesoderm and rhombomere transposition. Neuron 16: 487-500. 
IZPISUA-BELMONTE, J.C., DE ROBERTIS, E.M., STOREY, K.G. and STERN, C.D. (1993). The homeobox gene goosecoid and the origin of organizer cells in the early chick blastoderm. Cell 74: 645-59.

KANAI-AZUMA, M., KANAI, Y., GAD, J.M., TAJIMA, Y., TAYA, C., KUROHMARU, M., SANAI, Y., YONEKAWA, H., YAZAKI, K., TAM, P.P. et al. (2002). Depletion of definitive gut endoderm in sox17-null mutant mice. Development 129: 236779.

KELLER, R.E. (1975). Vital dye mapping of the gastrula and neurula of xenopus laevis. I. Prospective areas and morphogenetic movements of the superficial layer. Dev Biol 42: 222-41.

KELLER, R.E. (1976). Vital dye mapping of the gastrula and neurula of xenopus laevis. li. Prospective areas and morphogenetic movements of the deep layer. Dev Biol 51: 118-37.

KENGAKU, M. and OKAMOTO, H. (1995). Bfgf as a possible morphogen for the anteroposterior axis of the central nervous system in xenopus. Development 121: 3121-30.

KIENY, M., MAUGER, A. and SENGEL, P. (1972). Early regionalization of somitic mesoderm as studied by the development of axial skeleton of the chick embryo. Dev Biol 28: 142-61.

KIM, S.K., HEBROK, M., LI, E., OH, S.P., SCHREWE, H., HARMON, E.B., LEE, J.S. and MELTON, D.A. (2000). Activin receptor patterning of foregut organogenesis. Genes Dev 14: 1866-71.

KIM, S.K., HEBROK, M. and MELTON, D.A. (1997). Notochord to endoderm signaling is required for pancreas development. Development 124: 4243-52.

KINDER, S.J., TSANG, T.E., QUINLAN, G.A., HADJANTONAKIS, A.K., NAGY, A. and TAM, P.P. (1999). The orderly allocation of mesodermal cells to the extraembryonic structures and the anteroposterior axis during gastrulation of the mouse embryo. Development 126: 4691-701.

KINDER, S.J., TSANG, T.E., WAKAMIYA, M., SASAKI, H., BEHRINGER, R.R., NAGY, A. and TAM, P.P. (2001). The organizer of the mouse gastrula is composed of a dynamic population of progenitor cells for the axial mesoderm. Development 128: 3623-34.

KIRBY, M. L., LAWSON, A., STADT, H. A., KUMISKI, D. H., WALLIS, K. T., MCCRANEY, E., WALDO, K. L., LI, Y. X. and SCHOENWOLF, G. C. (2003). Hensen's node gives rise to the ventral midline of the foregut: implications for organizing head and heart development. Dev Bio/253: 175-188.

KUMAR, M., JORDAN, N., MELTON, D. and GRAPIN-BOTTON, A. (2003). Signals from lateral plate mesoderm instruct endoderm toward a pancreatic fate. Dev Biol 259: 109-22.

LAMB, T.M. and HARLAND, R.M. (1995). Fibroblast growth factor is a direct neural inducer, which combined with noggin generates anterior-posterior neural pattern. Development 121: 3627-36.

LAMMERT, E., CLEAVER, O. and MELTON, D. (2001). Induction of pancreatic differentiation by signals from blood vessels. Science 294: 564-7.

LAWSON, A. and SCHOENWOLF, G.C. (2003). Epiblast and primitive-streak origins of the endoderm in the gastrulating chick embryo. Development 130: 3491-501.

LAWSON, K.A., MENESES, J.J. and PEDERSEN, R.A. (1986). Cell fate and cell lineage in the endoderm of the presomite mouse embryo, studied with an intracellular tracer. Dev. Biol. 115: 325-39.

LAWSON, K.A., MENESES, J.J. and PEDERSEN, R.A. (1991). Clonal analysis of epiblast fate during germ layer formation in the mouse embryo. Development 113: 891-911.

LAWSON, K.A. and PEDERSEN, R.A. (1987). Cell fate, morphogenetic movement and population kinetics of embryonic endoderm at the time of germ layer formation in the mouse. Development 101: 627-52.

LE DOUARIN, N. (1963). Role du mésenchyme dans l'histogenèse hépatique chez l'embryon de poulet. C.R.Acad.Sc.Paris 257: 255-257.

LE DOUARIN, N. (1964a). Etude expérimentale de l'organogenèse du tube digestif et du foie chez l'embryon de poulet. Bulletin Biologique de la France et de la Belgique 543-676.

LE DOUARIN, N. (1964b). Induction de l'endoderme pré-hépatique par le mésoderme de l'aire cardiaque chez l'embryon de poulet. J.Embryol.exp.Morph. 12: 651-664.

LE DOUARIN, N. (1964c). Isolement expérimental du mésenchyme propre du foie et role morphogène de la composante mésodermique dans l'organogenèse hépatique. J.Embryol.exp.Morph. 12: 141-160.
LE DOUARIN, N. and BUSSONNET, C. (1966). Détermination précoce et role inducteur de l'endoderme pharyngien chez l'embryon de poulet. C.R.Acad.SC.Paris 263: 1241-1243.

LE DOUARIN, N. and WOLFF, E. (1967). Détermination précoce des ébauches de la thyrotide et du thymus chez l'embryon de poulet. C.R.Acad.SC.Paris 264: 940-942.

LICKERT, H., DOMON, C., HULS, G., WEHRLE, C., DULUC, I., CLEVERS, H., MEYER, B.I., FREUND, J.N. and KEMLER, R. (2000). Wnt/(beta)-catenin signaling regulates the expression of the homeobox gene $c d x 1$ in embryonic intestine. Development 127: 3805-13.

LICKERT, H. and KEMLER, R. (2002). Functional analysis of cis-regulatory elements controlling initiation and maintenance of early $c d \times 1$ gene expression in the mouse. Dev Dyn 225: 216-20.

LIN, R., HILL, R.J. and PRIESS, J.R. (1998). Pop-1 and anterior-posterior fate decisions in c. Elegans embryos. Cell 92: 229-39.

LIU, J.P., LAUFER, E. and JESSELL, T.M. (2001). Assigning the positional identity of spinal motor neurons: Rostrocaudal patterning of hox-c expression by fgfs, gdf11 and retinoids. Neuron 32: 997-1012.

LOGAN, C.Y. and MCCLAY, D.R. (1997). The allocation of early blastomeres to the ectoderm and endoderm is variable in the sea urchin embryo. Development 124: 2213-23.

LUDWIG, E. (1919). Zur entwicklungsgeschichte der leber, des pankreas und des vorderarms bei den ente und beim maulwurf. Anat. Hefte 1: 515-593.

MADEN, M. (1999). Heads or tails? Retinoic acid will decide. Bioessays 21: 809-12.

MALLO, G.V., RECHRECHE, H., FRIGERIO, J.M., ROCHA, D., ZWEIBAUM, A., LACASA, M., JORDAN, B.R., DUSETTI, N.J., DAGORN, J.C. and IOVANNA, J.L. (1997). Molecular cloning, sequencing and expression of the mrna encoding human $\mathrm{cdx} 1$ and cdx2 homeobox. Down-regulation of cdx1 and cdx2 mrna expression during colorectal carcinogenesis. Int $J$ Cancer 74: 35-44.

MANLEY, N.R. and CAPECCHI, M.R. (1995). The role of hoxa-3 in mouse thymus and thyroid development. Development 121: 1989-2003.

MANLEY, N.R. and CAPECCHI, M.R. (1998). Hox group 3 paralogs regulate the development and migration of the thymus, thyroid and parathyroid glands. Dev Biol 195: 1-15.

MAROM, K., SHAPIRA, E. and FAINSOD, A. (1997). The chicken caudal genes establish an anterior-posterior gradient by partially overlapping temporal and spatial patterns of expression. Mech Dev 64: 41-52.

MARTY, T., VIGANO, M.A., RIBEIRO, C., NUSSBAUMER, U., GRIEDER, N.C. and AFFOLTER, M. (2001). A hox complex, a repressor element and a 50 bp sequence confer regional specificity to a dpp-responsive enhancer. Development 128: 283345.

MARVIN, M.J., DIROCCO, G., GARDINER, A., BUSH, S.M. and LASSAR, A.B. (2001). Inhibition of wnt activity induces heart formation from posterior mesoderm. Genes Dev 15: 316-27.

MATHIS, L., KULESA, P.M. and FRASER, S.E. (2001). Fgf receptor signalling is required to maintain neural progenitors during hensen's node progression. Nat Cell Biol 3: 559-66.

MATSUMOTO, K., YOSHITOMI, H., ROSSANT, J. and ZARET, K.S. (2001). Liver organogenesis promoted by endothelial cells prior to vascular function. Science 294: 559-63.

MATSUSHITA, S. (1996). Fate mapping study of the endoderm of the 1.5-day-old chick embryo. Roux's Arch. Dev. Biol. 205: 225-231.

MATSUSHITA, S. (1999). Fate mapping study of the endoderm in the posterior part of the 1.5-day-old chick embryo. Dev Growth Differ 41: 313-9.

MCGREW, L.L., HOPPLER, S. and MOON, R.T. (1997). Wnt and fgf pathways cooperatively pattern anteroposterior neural ectoderm in xenopus. Mech Dev 69: 105-14.

MCPHERRON, A.C., LAWLER, A.M. and LEE, S.J. (1999). Regulation of anterior/ posterior patterning of the axial skeleton by growth/differentiation factor 11. Nat Genet 22: 260-4.

MISHINA, Y., SUZUKI, A., UENO, N. and BEHRINGER, R.R. (1995). Bmpr encodes a type i bone morphogenetic protein receptor that is essential for gastrulation during mouse embryogenesis. Genes \& Dev. 9: 3027-37.

MOLOTKOV, A., MOLOTKOVA, N. and DUESTER, G. (2005). Retinoic acid generated by Raldh2 in mesoderm is required for mouse dorsal endodermal pancreas development. Dev Dyn 232: 950-957. 
MUHR, J., JESSELL, T.M. and EDLUND, T. (1997). Assignment of early caudal identity to neural plate cells by a signal from caudal paraxial mesoderm. Neuron 19: 487502.

NARITA, N., BIELINSKA, M. and WILSON, D.B. (1997). Wild-type endoderm abrogates the ventral developmental defects associated with gata-4 deficiency in the mouse. Dev. Biol. 189: 270-274.

NIEUWKOOP, P.D. (1997). Short historical survey of pattern formation in the endomesoderm and the neural anlage in the vertebrates: The role of vertical and planar inductive actions. Cell Mol Life Sci 53: 305-18.

NISWANDER, L. and MARTIN, G.R. (1992). Fgf-4 expression during gastrulation, myogenesis, limb and tooth development in the mouse. Development 114: 755-68

NORDSTROM, U., JESSELL, T.M. and EDLUND, T. (2002). Progressive induction of caudal neural character by graded wnt signaling. Nat Neurosci 5: 525-32.

NOWICKI, J.L. and BURKE, A.C. (2000). Hox genes and morphological identity: Axial versus lateral patterning in the vertebrate mesoderm. Development 127: 4265-75.

OFFIELD, M.F., JETTON, T.L., LABOSKY, P.A., RAY, M., STEIN, R.W., MAGNUSON, M.A., HOGAN, B.L. and WRIGHT, C.V. (1996). Pdx-1 is required for pancreatic outgrowth and differentiation of the rostral duodenum. Development 122: 983-95.

OHNEDA, K., MIRMIRA, R.G., WANG, J., JOHNSON, J.D. and GERMAN, M.S. (2000). The homeodomain of $\mathrm{pdx}-1$ mediates multiple protein-protein interactions in the formation of a transcriptional activation complex on the insulin promoter. Mol Cell Biol 20: 900-11.

OKADA, T.S. (1953). On the role of the mesoderm in the differentiation of the presumptive endoderm. Mem. Coll. Sci. Univ. Kyoto 20: 157-162.

OKADA, T.S. (1954a). Experimental studies on the differentiation of the endodermal organs in amphibia. I. Significance of the mesenchymatous tissue to the differentiation of the presumptive endoderm. Mem. Coll. Sci. Univ. Kyoto 21: 1-6.

OKADA, T.S. (1954b). Experimental studies on the differentiation of the endodermal organs in amphibia. li. Differentiating potencies of the presumptive endoderm in the presence of the mesodermal tissues. Mem. Coll. Sci. Univ. Kyoto 21: 7-14.

PANGANIBAN, G.E., REUTER, R., SCOTT, M.P. and HOFFMANN, F.M. (1990). A drosophila growth factor homolog, decapentaplegic, regulates homeotic gene expression within and across germ layers during midgut morphogenesis. Development 110: 1041-50.

PARAMESWARAN, M. and TAM, P.P. (1995). Regionalisation of cell fate and morphogenetic movement of the mesoderm during mouse gastrulation. Dev Genet 17: 16-28.

PARK, F.D. and PRIESS, J.R. (2003). Establishment of pop-1 asymmetry in early C. Elegans embryos. Development 130: 3547-56.

PEARCE, J.J., PENNY, G. and ROSSANT, J. (1999). A mouse cerberus/danrelated gene family. Dev Biol 209: 98-110.

PFEFFER, P.L., DE ROBERTIS, E.M. and IZPISUA-BELMONTE, J.C. (1997). Crescent, a novel chick gene encoding a frizzled-like cysteine-rich domain, is expressed in anterior regions during early embryogenesis. Int J Dev Biol 41: 449-58.

POLLOCK, R.A., JAY, G. and BIEBERICH, C.J. (1992). Altering the boundaries of hox3.1 expression: Evidence for antipodal gene regulation. Cel/ 71: 911-23.

POURQUIE, O., FAN, C.M., COLTEY, M., HIRSINGER, E., WATANABE, Y., BREANT, C., FRANCIS-WEST, P., BRICKELL, P., TESSIER-LAVIGNE, M. and LE DOUARIN, N.M. (1996). Lateral and axial signals involved in avian somite patterning: A role for bmp4. Cell 84: 461-471.

POWNALL, M.E., TUCKER, A.S., SLACK, J.M. and ISAACS, H.V. (1996). Efgf, xcad3 and hox genes form a molecular pathway that establishes the anteroposterior axis in xenopus. Development 122: 3881-92.

PSYCHOYOS, D. and STERN, C.D. (1996). Fates and migratory routes of primitive streak cells in the chick embryo. Development 122: 1523-34.

RESHEF, R., MAROTO, M. and LASSAR, A.B. (1998). Regulation of dorsal somitic cell fates: Bmps and noggin control the timing and pattern of myogenic regulator expression. Genes Dev 12: 290-303.

REUTER, R., GRUNEWALD, B. and LEPTIN, M. (1993). A role for the mesoderm in endodermal migration and morphogenesis in drosophila. Development 119: 1135-45.

RIESE, J., YU, X., MUNNERLYN, A., ERESH, S., HSU, S.C., GROSSCHEDL, R. and BIENZ, M. (1997). Lef-1, a nuclear factor coordinating signaling inputs from wingless and decapentaplegic. Cel/ 88: 777-87.
ROBERTS, D.J. (2000). Molecular mechanisms of development of the gastrointestinal tract. Dev Dyn 219: 109-20.

ROBERTS, D.J., JOHNSON, R.L., BURKE, A.C., NELSON, C.E., MORGAN, B.A. and TABIN, C. (1995). Sonic hedgehog is an endodermal signal inducing bmp-4 and hox genes during induction and regionalization of the chick hindgut. Development 121: 3163-74.

ROBERTS, D.J., SMITH, D.M., GOFF, D.J. and TABIN, C.J. (1998). Epithelialmesenchymal signaling during the regionalization of the chick gut. Development 125: $2791-801$

ROBINSON, A. (1903). The early stages of the development of the pericardium. J. Anat.Physiol. 37: 1-17.

RODRIGUEZ, T.A., CASEY, E.S., HARLAND, R.M., SMITH, J.C. and BEDDINGTON, R.S. (2001). Distinct enhancer elements control hex expression during gastrulation and early organogenesis. Dev Biol 234: 304-16.

ROELEN, B.A., GOUMANS, M.J., VAN ROOIJEN, M.A. and MUMMERY, C.L. (1997). Differential expression of bmp receptors in early mouse development. Int J Dev Biol 41: 541-9.

ROSENQUIST, G.C. (1972). Endoderm movements in the chick embryo between the early short streak and head process stages. J Exp Zool 180: 95-103.

ROSSI, J.M., DUNN, N.R., HOGAN, B.L. and ZARET, K.S. (2001). Distinct mesodermal signals, including bmps from the septum transversum mesenchyme, are required in combination for hepatogenesis from the endoderm. Genes Dev 15: 1998-2009.

RUIZ I ALTABA, A., PLACZEK, M., BALDASSARE, M., DODD, J. and JESSELL, T.M. (1995). Early stages of notochord and floor plate development in the chick embryo defined by normal and induced expression of hnf-3 beta. Dev Biol 170: 299-313

SAKIYAMA, J., YOKOUCHI, Y. and KUROIWA, A. (2000). Coordinated expression of hoxb genes and signaling molecules during development of the chick respiratory tract. Dev Biol 227: 12-27.

SAKIYAMA, J., YOKOUCHI, Y. and KUROIWA, A. (2001). Hoxa and hoxb cluster genes subdivide the digestive tract into morphological domains during chick development. Mech Dev 101: 233-6.

SCHNEIDER, V. A. and MERCOLA, M. (2001). Wnt antagonism initiates cardiogenesis in Xenopus laevis. Genes Dev 15: 304-315.

SCHROEDER, D.F. and MCGHEE, J.D. (1998). Anterior-posterior patterning within the caenorhabditis elegans endoderm. Development 125: 4877-87.

SCHUBERT, M., YU, J. K., HOLLAND, N. D., ESCRIVA, H., LAUDET, V. and HOLLAND, L. Z. (2005). Retinoic acid signaling acts via Hox1 to establish the posterior limit of the pharynx in the chordate amphioxus. Development 132: 61-73.

SCHULTHEISS, T.M., BURCH, J.B. and LASSAR, A.B. (1997). A role for bone morphogenetic proteins in the induction of cardiac myogenesis. Genes Dev. 11: 451-62.

SCHULTHEISS, T.M. and LASSAR, A.B. (1997). Induction of chick cardiac myogenesis by bone morphogenetic proteins. Cold Spring Harb Symp Quant Biol 62: 413-9.

SCHULTHEISS, T.M., XYDAS, S. and LASSAR, A.B. (1995). Induction of avian cardiac myogenesis by anterior endoderm. Development 121: 4203-14.

SENO, H., OSHIMA, M., TANIGUCHI, M.A., USAMI, K., ISHIKAWA, T.O., CHIBA, T. and TAKETO, M.M. (2002). Cdx2 expression in the stomach with intestinal metaplasia and intestinal-type cancer: Prognostic implications. Int JOnco/21:76974.

SERLS, A. E., DOHERTY, S., PARVATIYAR, P., WELLS, J. M. and DEUTSCH, G. H. (2005). Different thresholds of fibroblast growth factors pattern the ventral foregut into liver and lung. Development 132: 35-47.

SHAWLOT, W. and BEHRINGER, R.R. (1995). Requirement for lim1 in head-organizer function. Nature 374: 425-30.

SHIOTSUGU, J., KATSUYAMA, Y., ARIMA, K., BAXTER, A., KOIDE, T., SONG, J., CHANDRARATNA, R. A. and BLUMBERG, B. (2004). Multiple points of interaction between retinoic acid and FGF signaling during embryonic axis formation. Development 131: 2653-2667.

SILBERG, D.G., SULLIVAN, J., KANG, E., SWAIN, G.P., MOFFETT, J., SUND, N.J., SACKETT, S.D. and KAESTNER, K.H. (2002). Cdx2 ectopic expression induces gastric intestinal metaplasia in transgenic mice. Gastroenterology 122: 689-96.

SIMEONE, A., ACAMPORA, D., NIGRO, V., FAIELLA, A., D'ESPOSITO, M., STORNAIUOLO, A., MAVILIO, F. and BONCINELLI, E. (1991). Differential regulation by retinoic acid of the homeobox genes of the four hox loci in human embryonal carcinoma cells. Mech Dev 33: 215-27. 
SMITH, D.M., NIELSEN, C., TABIN, C.J. and ROBERTS, D.J. (2000). Roles of bmp signaling and $\mathrm{k} \times 2.5$ in patterning at the chick midgut-foregut boundary. Development 127: 3671-81

SMITH, D.M. and TABIN, C.J. (2000). Clonally related cells are restricted to organ boundaries early in the development of the chicken gut to form compartment boundaries. Dev Biol 227: 422-31.

SOLLOWAY, M.J. and ROBERTSON, E.J. (1999). Early embryonic lethality in bmp5;bmp7 double mutant mice suggests functional redundancy within the $60 \mathrm{a}$ subgroup. Development 126: 1753-68.

STAEHLING-HAMPTON, K. and HOFFMANN, F.M. (1994). Ectopic decapentaplegic in the drosophila midgut alters the expression of five homeotic genes, dpp and wingless, causing specific morphological defects. Dev Biol 164: 502-12.

STAEHLING-HAMPTON, K., HOFFMANN, F.M., BAYLIES, M.K., RUSHTON, E. and BATE, M. (1994). Dpp induces mesodermal gene expression in drosophila. Nature 372: 783-6.

STAFFORD, D. and PRINCE, V. E. (2002). Retinoic acid signaling is required for a critical early step in zebrafish pancreatic development. Curr Bio/12: 1215-1220.

STAFFORD, D., HORNBRUCH, A., MUELLER, P. R. and PRINCE, V. E. (2004). A conserved role for retinoid signaling in vertebrate pancreas development. Dev Genes Evo/214: 432-441.

STOREY, K.G., GORIELY, A., SARGENT, C.M., BROWN, J.M., BURNS, H.D., ABUD, H.M. and HEATH, J.K. (1998). Early posterior neural tissue is induced by fg in the chick embryo. Development 125: 473-84.

SUH, E., CHEN, L., TAYLOR, J. and TRABER, P.G. (1994). A homeodomain protein related to caudal regulates intestine-specific gene transcription. $\mathrm{Mol}$ Cel/ Biol 14: 7340-51.

SUMIYA, M. and MIZUNO, T. (1974). [differentiation of the endoderm in digestive tract of the chick embryo cultured in vitelline membrane, in absence of mesenchyma]. $C$ R Acad Sci Hebd Seances Acad Sci D 278: 1529-32.

SWINDELL, E.C., THALLER, C., SOCKANATHAN, S., PETKOVICH, M., JESSELL, T.M. and EICHELE, G. (1999). Complementary domains of retinoic acid production and degradation in the early chick embryo. Dev Biol 216: 282-96.

TAKATA, C. (1960). The differentiation in vivo of the isolated endoderm under the influence of the mesoderm in triturus pyrrhogaster. Embryologica 5: 38-70.

TAKIGUCHI-HAYASHI, K. and YASUGI, S. (1990). Transfilter analysis of the inductive influence of proventricular mesenchyme on stomach epithelial differentiation of chick embryos. Dev Biol (Roux's Archives) 198: 460-466.

TAM, P.P., PARAMESWARAN, M., KINDER, S.J. and WEINBERGER, R.P. (1997). The allocation of epiblast cells to the embryonic heart and other mesodermal lineages: The role of ingression and tissue movement during gastrulation. Development 124: 1631-42.

TENNYSON, V.M., GERSHON, M.D., SHERMAN, D.L., BEHRINGER, R.R., RAZ, R., CROTTY, D.A. and WOLGEMUTH, D.J. (1993). Structural abnormalities associated with congenital megacolon in transgenic mice that overexpress the hoxa-4 gene. Dev Dyn 198: 28-53.

TENNYSON, V.M., GERSHON, M.D., WADE, P.R., CROTTY, D.A. and WOLGEMUTH, D.J. (1998). Fetal development of the enteric nervous system of transgenic mice that overexpress the hoxa-4 gene. Dev Dyn 211: 269-91.

THOMAS, P.Q., BROWN, A. and BEDDINGTON, R.S. (1998). Hex: A homeobox gene revealing peri-implantation asymmetry in the mouse embryo and an early transient marker of endothelial cell precursors. Development 125: 85-94.

TISO, N., FILIPPI, A., PAULS, S., BORTOLUSSI, M. and ARGENTON, F. (2002). Bmp signalling regulates anteroposterior endoderm patterning in zebrafish. Mech Dev 118: 29-37.

TREMBLAY, K.D., HOODLESS, P.A., BIKOFF, E.K. and ROBERTSON, E.J. (2000). Formation of the definitive endoderm in mouse is a smad2-dependent process. Development 127: 3079-90.

TREMBLAY, K. D. and ZARET, K. S. (2005). Distinct populations of endoderm cells converge to generate the embryonic liver bud and ventral foregut tissues. Dev Biol 280: 87-99.

TREMML, G. and BIENZ, M. (1989). Homeotic gene expression in the visceral mesoderm of drosophila embryos. EMBOJ 8: 2677-85.
TROELSEN, J.T., MITCHELMORE, C., SPODSBERG, N., JENSEN, A.M., NOREN, O and SJOSTROM, H. (1997). Regulation of lactase-phlorizin hydrolase gene expression by the caudal-related homoeodomain protein cdx-2. Biochem J $322(\mathrm{Pt}$ 3): 833-8.

TZAHOR, E. and LASSAR, A.B. (2001). Wnt signals from the neural tube block ectopic cardiogenesis. Genes Dev 15: 255-60.

VAN DEN AKKER, E., FORLANI, S., CHAWENGSAKSOPHAK, K., DE GRAAFF, W., BECK, F., MEYER, B.I. and DESCHAMPS, J. (2002). Cdx1 and cdx2 have overlapping functions in anteroposterior patterning and posterior axis elongation. Development 129: 2181-93.

WALLACE, K.N. and PACK, M. (2003). Unique and conserved aspects of gut development in zebrafish. Dev Biol 255: 12-29.

WARGA, R.M. and NUSSLEIN-VOLHARD, C. (1999). Origin and development of the zebrafish endoderm. Development 126: 827-38.

WAROT, X., FROMENTAL-RAMAIN, C., FRAULOB, V., CHAMBON, P. and DOLLE, P. (1997). Gene dosage-dependent effects of the hoxa-13 and hoxd-13 mutations on morphogenesis of the terminal parts of the digestive and urogenital tracts. Development 124: 4781-91.

WELLS, J.M. and MELTON, D.A. (2000). Early mouse endoderm is patterned by soluble factors from adjacent germ layers. Development 127: 1563-72.

WILLIER, B.H. and RAWLES, M.E. (1931). Developmental relations of heart and liver in chorio-allantoic grafts of whole chick blastoderms. Anat. Rec. 48: 277-301.

WINNIER, G., BLESSING, M., LABOSKY, P.A. and HOGAN, B.L.M. (1995). Bone morphogenetic protein- 4 is required for mesoderm formation and patterning in the mouse. Genes Dev. 9: 2105-2116.

YAGI, O.K., AKIYAMA, Y. and YUASA, Y. (1999). Genomic structure and alterations of homeobox gene cdx2 in colorectal carcinomas. Br J Cancer 79: 440-4.

YAMAMOTO, M., MENO, C., SAKAI, Y., SHIRATORI, H., MOCHIDA, K., IKAWA, Y., SAIJOH, Y. and HAMADA, H. (2001). The transcription factor foxh1 (fast) mediates nodal signaling during anterior-posterior patterning and node formation in the mouse. Genes Dev. 15: 1242-56.

YANZE, N., SPRING, J., SCHMIDLI, C. and SCHMID, V. (2001). Conservation of hox/ parahox-related genes in the early development of a cnidarian. Dev Biol 236: 8998.

YASUGI, S. (1993). Role of epithelial-mesenchymal interactions in differentiation of epithelium of vertebrate digestive organs. Develop. Growth\&Differ. 35: 1-9.

YASUGI, S., MATSUSHITA, S. and MIZUNO, T. (1985). Gland formation induced in the allantoic and small-intestinal endoderm by the proventricuar mesenchyme is not coupled with pepsinogen expression. Differentiation 30: 47-52.

YASUGI, S. and MIZUNO, T. (1978). Differentiation of the digestive tract epithelium under the influence of the heterologous mesenchyme of the digestive tract in the bird embryos. Develop. Growth\&Differ. 20: 261-267.

YASUGI, S., TAKEDA, H. and FUKUDA, K. (1991). Early determination of developmental fate in presumptive intestinal endoderm of the chicken embryo. Develop. Growth\&Differ. 33: 235-241.

YATSKIEVYCH, T.A., PASCOE, S. and ANTIN, P.B. (1999). Expression of the homebox gene hex during early stages of chick embryo development. Mech Dev 80: 107-9.

YOKOUCHI, Y., SAKIYAMA, J. and KUROIWA, A. (1995). Coordinated expression of abd-b subfamily genes of the hoxa cluster in the developing digestive tract of chick embryo. Dev Biol 169: 76-89.

YOSHITOMI, H. and ZARET, K. S. (2004). Endothelial cell interactions initiate dorsal pancreas development by selectively inducing the transcription factor Ptf1a. Development 131: 807-817.

ZAKANY, J., KMITA, M., ALARCON, P., DE LA POMPA, J.L. and DUBOULE, D. (2001). Localized and transient transcription of hox genes suggests a link between patterning and the segmentation clock. Cel/ 106: 207-17.

ZEYNALI, B. and DIXON, K.E. (1998). Effects of retinoic acid on the endoderm in xenopus embryos. Dev Genes Evol 208: 318-26.

ZEYNALI, B., KALIONIS, B. and DIXON, K.E. (2000). Determination of anterior endoderm in xenopus embryos. Dev Dyn 218: 531-6. 